\title{
TEACHING WRITING AND ERROR CORRECTION IN AN ENGLISH FOR SPECIFIC PURPOSES CLASSROOM IN 2014-2020 IN UKRAINE
}

\author{
Iryna Didenko ${ }^{1}$, Nataliia Zhukova ${ }^{2}$ \\ ${ }^{1}$ Taras Shevchenko National University of Kyiv, Ukraine \\ ${ }^{2}$ National University “Zaporizhzhia Polytechnic”, Zaporizhzhia, Ukraine
}

\begin{abstract}
Before 2014 teaching writing in the English for Specific Purposes course at Ukrainian universities was pretty similar to the General English course at secondary schools with strong emphasis on grammar. But the British Council "English for Universities" project started in 2014 in Ukraine triggered dramatic changes in teaching writing and error correction in an ESP class. Namely, catering the course for meeting the learners' needs, identifying the genres to focus on, using three approaches to teaching writing: product, process and socialconstructionist approaches, peer-learning and proofreading, emphasis on developing writing sub-skills rather than polishing grammar, introducing brand-new approach to assessment and evaluation of a piece of writing (peer evaluation and assessment, introducing the system of clear and concise criteria for assessment). The article describes not only the changes that were introduced, but also the impact of these changes on the readiness of graduates and students to function successfully in a professional environment relying on their feedback. The results of a quantitative research conducted in 4 focus groups: $30(20+10)$ Master's degree students and 30 $(20+10)$ 1st-year Bachelor's degree students from two universities of Ukraine are depicted.
\end{abstract}

Key words: approaches to teaching writing, English for Specific Purposes, error correction, feedback, peer evaluation, writing skills, writing sub-skills

\section{INTRODUCTION}

The dates chosen for the study are tightly connected with the "English for Universities" project that was initiated by the British Council in Ukraine in 2014 and lasted till 2019. Initially, 15 national public universities were involved; the number grew to 32 finally.

The "English for Universities" project was aimed to help Ukrainian institutions develop sustainable English language teaching capacity, introduce standards at universities and improve language teaching and learning so that there were more opportunities for effective international collaboration (English for Universities). It was the driving force of substantial transformations in approaches to teaching English for Specific Purposes and English as a Medium of Instruction at Ukrainian higher educational institutions. The findings of the baseline study were published in 2017 (Bolitho, West 2017), whereas the impact study was

Submitted October $12^{\text {th }}, 2020$, accepted for publication February $23^{\text {rd }}, 2021$

Corresponding author: Nataliia Zhukova. National University "Zaporizhzhia Polytechnic", 69063 Zaporizhzhia,

Žukovskogo 64, Ukraine |E-mail: nmzhukova1@gmail.com 
carried out in 2018 and presented in 2019 (Borg 2019). In this research, the impact of the project on teaching writing in an ESP course at Taras Shevchenko National University of Kyiv and National University "Zaporizhzhia Polytechnic" was analyzed with the primary focus on the feedback from the students.

\section{RESEARCH BACKGROUND}

Writing in English is attributed an enormous importance for students in higher education and on professional training courses, and gaining fluency in the conventions of writing in English is a must for the learners "to better understand their disciplines, to establish their careers or to successfully navigate their learning" (Hyland 2013, 95).

Teaching writing in ESP courses at Ukrainian universities has been the subject of a few researches. Thus, the development of English writing skills of students mastering Psychology in the course of Internet-assisted project work has been studied (Tarnopolsky 2013). The writing skills required by the students of IT specialisms (Dychka et. al., 2016), as well as the abilities and competences needed by them for technical writing (Lubianova 2016) have been investigated. The implications of the needs analysis of social pedagogy students for developing academic writing skills have been outlined (Palka 2016, 125).

In 2005 there appeared a significant document, ESP National Curriculum for universities (ESP National Curriculum 2005). But it was barely implemented until 2014 when more and more universities in Ukraine started to use it within the "English for Universities" project. The guidelines from this document were applied to syllabus design at National University "Zaporizhzhia Polytechnic" (Zaporizhzhia National Technical University at that time) in 2017-2018 as this institution joined the project in 2016.

It should be noted that Taras Shevchenko National University of Kyiv did not accept the ESP National Curriculum as a guidance, despite being in the project from the very beginning, and even though the ESP teachers of this university were trained in the framework of the mentioned project and introduced changes to their approaches to teaching ESP.

According to the ESP National Curriculum, the objectives for the Bachelor's degree students, who are expected to demonstrate B2 level of language proficiency, in terms of writing are as follows:

"By the end of the ESP course students will be able to:

- write clear, detailed texts for variety of purposes related to personal and professional areas;

- write detailed study- and specialism-related assignments and reports in standard format;

- draft and produce business and professional correspondence;

- take messages from telephone and word of mouth accurately;

- write summaries, minutes, etc. with high degree of accuracy;

- fill in forms for academic or professional purposes with high degree of accuracy;

- use basic cohesive devices to link their utterances into clear, coherent discourse;

- perform and respond to a wide range of language functions, using exponents flexibly" (Bakaieva 2005, 37).

Bearing in mind that the curriculum was released in 2005, an ESP course was to be adjusted to the needs of the students with the growing interest in the academic mobility programmes and work abroad, which require international exam certificates. We analysed writing sections of 10 currently valid international exams to see what subskills are given priority in testing and, therefore, should be polished in an ESP classroom. 
The following exams were under consideration within this study: TOEFL ITP (Test of English as a Foreign Language: Institutional Testing Program), TOEIC (Test of English for International Communication), IELTS Academic (International English Language Testing System: Academic), PTE Academic (Pearson Test of English Academic), Aptis (General, Advanced), Linguaskill Business, B1 Business Preliminary, B2 Business Vantage, C1 Business Higher, GMAT (Graduate Management Admission Test). For a complete overview of the international exams in terms of writing sub-skills follow the link to the Google document (Didenko, Zhukova 2020).

The writing sub-skills tested in the international ESP and EAP exams fall into 2 categories: those related to accuracy and to communicating ideas (for the list of the writing sub-skills see (Spratt 2015, 37)).

The aforementioned exams focus on such writing sub-skills related to accuracy as spelling, forming letters, joining letters together, writing legibly, punctuating, using correct layouts, choosing the right vocabulary, using grammar correctly, joining sentences, using paragraphs correctly. The following writing sub-skills related to communicating ideas are examined: using appropriate style and register, organising ideas in a helpful way, using features typical of a text type one is writing, joining words and sentences clearly, using appropriate functions to express meaning, e.g. narrating, complaining, requesting, thanking, summarising, concluding.

It was revealed that all of the exams, but for the exams using computers (e.g. Linguaskill Business, Aptis, PTE Academic), test all of the writing sub-skills to a lesser or greater extent. The exams in the e-format do not check the ability of writing legibly, forming and joining letters correctly. It should be noted that TOEFL ITP examines only the ability to choose the right vocabulary and use appropriate style and register.

The ESP syllabus at National University "Zaporizhzhia Polytechnic" now comprises four modules, namely "Socializing in Academic and Professional Environments", "Searching for and Processing Information", "Presenting Information" and "Application Procedure". Writing skills are mainly focused on in "Searching for and Processing Information", "Presenting Information", and "Application Procedure" modules.

At Taras Shevchenko National University of Kyiv, teaching writing skills is not allotted for a separate module and is carried out during the whole course.

While identifying the subskills to develop in an ESP course, the teacher cannot ignore the requirements of the contemporary world, so teaching writing skills is integral with developing soft skills. Fostering collaboration, interaction and peer feedback, alongside autonomous learning and critical thinking was emphasized in the study of academic skills for a $\mathrm{PhD}$ program (Balula et al. 2019, 303), with writing being one of the main skills, together with collaboration and presentation. The multidisciplinary nature of the process was noted by the researchers and can be extrapolated onto the ESP domain.

We rely on the definition of academic skills as "transferable skills which underpin the learning of HE (higher education - authors' remark) students, enabling them to be confident, independent critical thinkers and reflective learners". We also adhere to the viewpoint that these skills comprise "finding and evaluating information; academic writing; reading and note-taking; preparing for exams; working in groups; presentation skills; referencing and avoiding plagiarism; time management; and critical thinking" (Howard 2012, 76). In this study, we regarded how the changes in teaching writing influenced students' mastering soft skills. 


\section{METHODS OF RESEARCH}

The research was undertaken in the 2019-2020 academic year at two Ukrainian universities, Taras Shevchenko National University of Kyiv and National University "Zaporizhzhia Polytechnic". The total number of respondents was 60 people: 30 firstyear Bachelor degree students (20 students from Taras Shevchenko National University of Kyiv and 10 ones from National University "Zaporizhzhia Polytechnic") and 30 Master's degree students (20 students from Taras Shevchenko National University of Kyiv and 10 ones from National University "Zaporizhzhia Polytechnic"). Such a choice was reasoned by the aim of the research: to study the changes in teaching writing skills in the framework of an English for Specific Purposes course that is taught during the first year of study in Bachelor's programme. Master's degree students had this course in the 2014-2015 academic year (when the British Council "English for Universities" project had just been launched), and first-year Bachelor's degree students had this course in the 2019-2020 academic year (after the completion of the abovementioned project).

The survey was conducted via email and Moodle LMS. The research was quantitative and contained questions adapted from the baseline study by R. Bolitho and R. West (Bolitho, West 2017, 31-64) and the impact study by S. Borg (Borg 2019, 10-13). The types of questions were multiple-choice, close- and open-ended questions.

The survey questions were formulated as follows:

1. In your opinion, how relevant to your future profession are the text types you were taught to write in the ESP course?

Extremely relevant / fairly relevant / not relevant

2. What genres of texts were you taught to write in the ESP course?

3. Did you have in-class or home writing activities?

Mostly in-class writing / both / mostly home writing / only home writing

4. Who evaluated (gave feedback on) your writing tasks?

Teacher only / teacher and peers / teacher, peers and me

5. All the writing tasks were assessed by the teacher.

Agree / disagree

6 . What was the method of error correction?

All the errors were marked and corrected / The errors were underlined without correction / The feedback was written with recommendations what to focus on

7. What approach was used for teaching writing:

Sample model / stages of analysis and writing / focus on emotional impact of the text on the reader / all mentioned approaches

It should be mentioned that some of the theoretical questions were adapted for students understanding, for instance, in question \#7 names of the approaches were changed respectively: "a product approach" - for "a sample model approach", "a process approach" - for "stages of analysis and writing" approach, and "a social-constructionist approach" - for "a focus on emotional impact of the text on the reader" approach.

\section{RESEARCH FINDINGS}

The research has demonstrated a significant paradigm shift in approaches to teaching writing in ESP, in content of this course, in assessment and error correction. In both universities the level of students' satisfaction increased dramatically. 


\subsection{Writing text types taught in the ESP course}

Students of both universities were asked what types of texts they were taught to write in an ESP course. The text types listed by the students of both universities are represented in Table 1.

Table 1 Text types studied in the ESP course

\begin{tabular}{|l|l|l|}
\hline & $\begin{array}{l}\text { 1st-year Bachelor's Degree students } \\
\text { (had an ESP course in 2019-2020 } \\
\text { academic year) }\end{array}$ & $\begin{array}{l}\text { Master's Degree students } \\
\text { (had an ESP course in } \\
\text { 2014-2015 academic year) }\end{array}$ \\
\hline $\begin{array}{l}\text { Taras Shevchenko } \\
\text { National University of } \\
\text { Kyiv }\end{array}$ & $\begin{array}{l}\text { Email } \\
\text { Statement of purpose } \\
\text { Summary } \\
\text { CV } \\
\text { Cover letter }\end{array}$ & $\begin{array}{l}\text { Essay } \\
\text { Abstract of an article } \\
\text { CV }\end{array}$ \\
\hline $\begin{array}{l}\text { National University } \\
\text { "Zaporizhzhia } \\
\text { Polytechnic" }\end{array}$ & $\begin{array}{l}\text { Email } \\
\text { CV }\end{array}$ & $\begin{array}{l}\text { CV } \\
\text { Cover letter } \\
\text { Motivational letter for an acticle } \\
\text { mobility program } \\
\text { Abstract of an article } \\
\text { Conference proceedings }\end{array}$ \\
\hline
\end{tabular}

As it is seen from the table the types of the writing texts in the ESP curricula moved from more academic and research spheres to more practical and applied fields. If before the writing tasks were targeted more at teaching the learners how to write different types of essay and abstracts of research papers or articles related to their specialisms, now at both universities writing tasks that students get will help them in future to get a job $(\mathrm{CV}$, cover letter), to apply for an academic mobility programme (statement of purpose or motivational letter), or successfully cope with everyday business communication (email).

At National University "Zaporizhzhia Polytechnic" students are encouraged to participate in the "Week of Science" events held annually, therefore, they also have to master writing conference proceedings.

The students who participated in this research also noted the increased relevance of writing text types they are taught today to their professional needs. This can be seen in the following diagrams (Figures 1 and 2).

The findings of the research demonstrated that at both universities the Master's degree students, who had their ESP course in the 2014-2015 academic year, considered the writing text types they were taught between fairly relevant and not relevant, however, the first-year students, who learned this course in 2019-2020 academic year, distributed their votes between extremely relevant and fairly relevant. Thus, writing tasks have become more job-related and better meet students' needs now than before the project. 


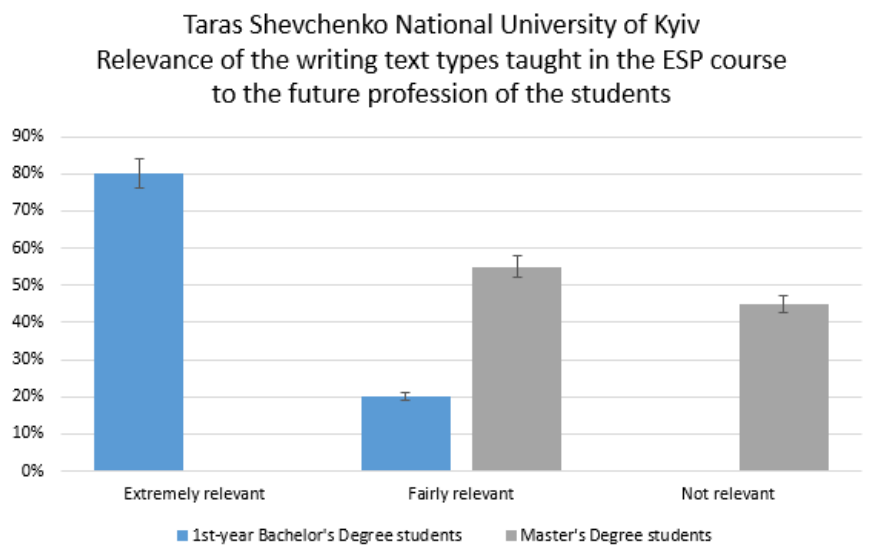

Fig. 1 Relevance of the writing tasks taught in the ESP course to the future profession of the students of Taras Shevchenko National University of Kyiv in 2014 and 2020

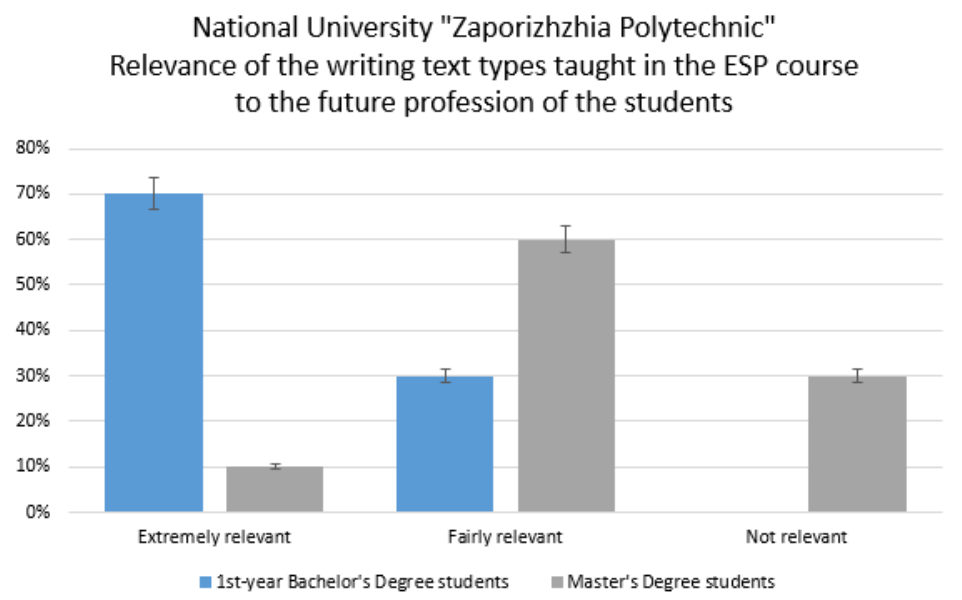

Fig. 2 Relevance of the writing tasks taught in the ESP course to the future profession of the students of National University "Zaporizhzhia Polytechnic" in 2014 and 2020

\subsection{Correlation of in-class and home writing activities in the ESP course}

The research has demonstrated that if in the 2014-2015 academic year students got writing tasks mostly as their home task, the feedback of the current first-year students has shown that today in an ESP course the advantages of an in-class writing (drafting, proofreading, self-reflection and peer feedback) are widely used. The following figures ( 3 and 4) prove that at both universities Writing is becoming more and more taught both in-class and at home. 


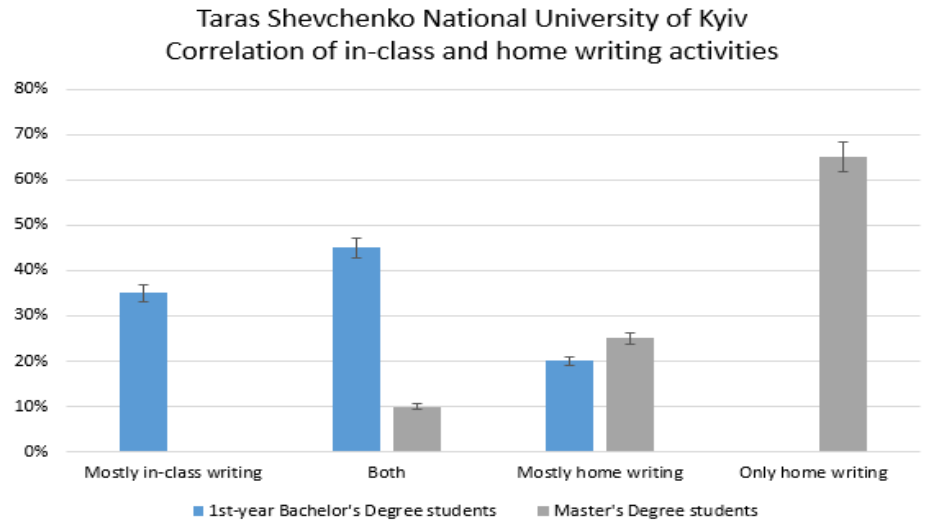

Fig. 3 Correlation of in-class and home writing activities at Taras Shevchenko National University of Kyiv in 2014 and 2020.

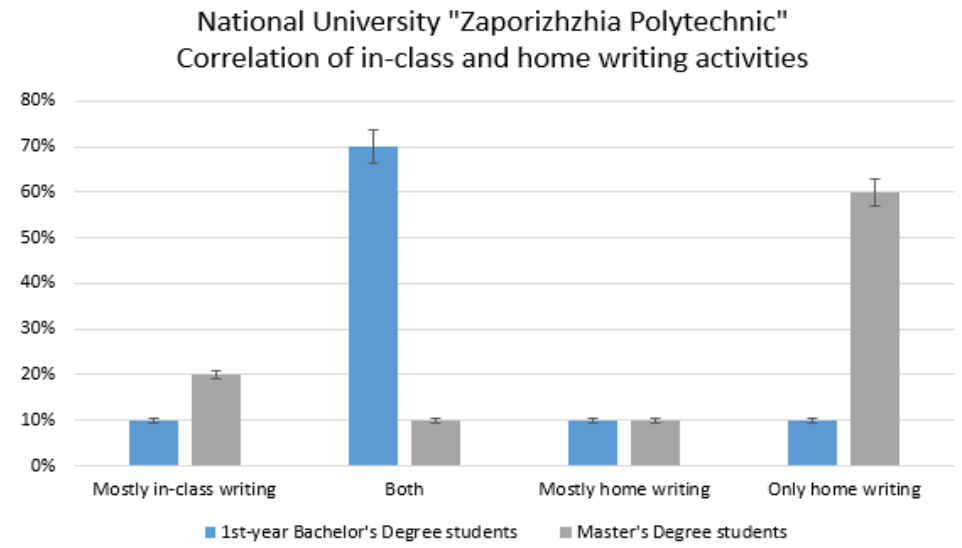

Fig. 4 Correlation of in-class and home writing activities at National University "Zaporizhzhia Polytechnic" in 2014 and 2020.

\subsection{Assessment and evaluation of writing activities}

Master's degree students pointed out that in the 2014-2015 academic year, when they had an ESP course, they were working alone on writing tasks, even more, one of the compulsory requirements was their individual work on a writing task. However, $1^{\text {st }}$ year students noticed the increasing involvement of peers in the process of developing a writing text as well as engaging their feedback on the finished piece of writing. Moreover, selfevaluation and self-reflection are the tools widely used as tools for teaching and learning writing. The results of the survey can be seen in the following figures. 


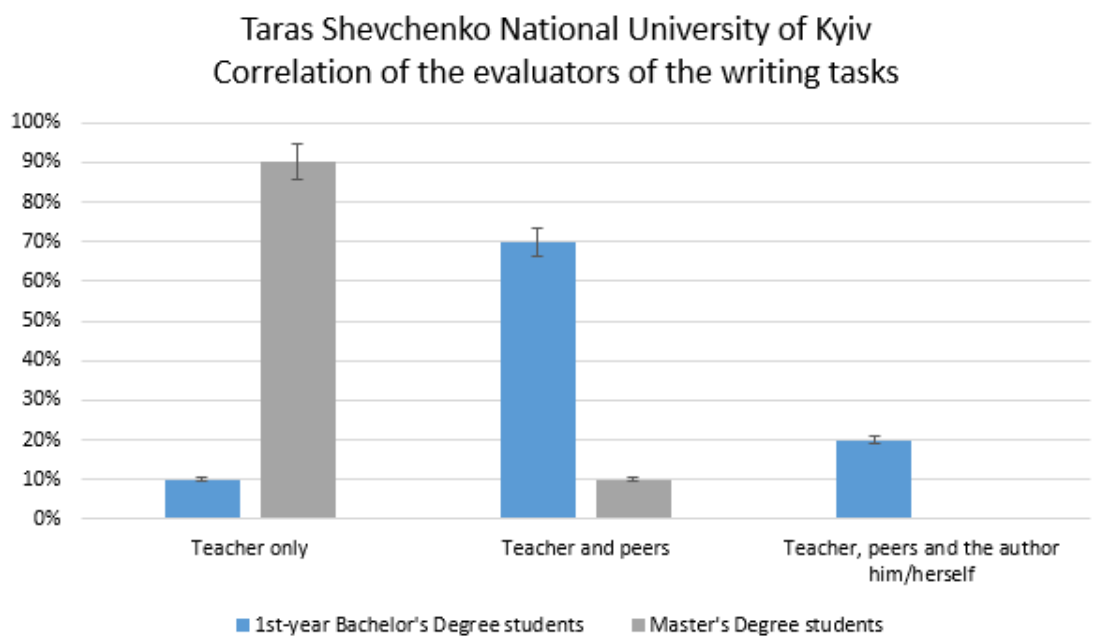

Fig. 5 Correlation of the evaluators of the writing tasks at Taras Shevchenko National University of Kyiv in 2014 and 2020.

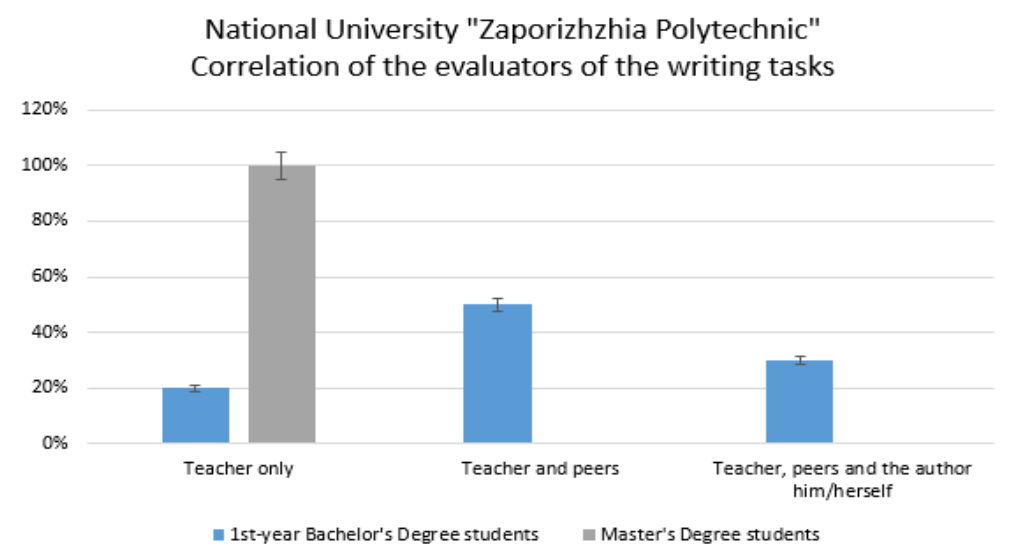

Fig. 6 Correlation of the evaluators of the writing tasks

at National University "Zaporizhzhia Polytechnic"in 2014 and 2020.

According to the results of the survey, participants of the ESP course now benefit more from the involvement of peers and usage of self-evaluation tools. The same trend is seen in terms of the approach to assessment. Five years ago the teachers used to assess every single piece of writing of their students. Now ESP teachers more often introduce formative assessment in order to help their students improve their writing skills. The following figures ( 7 and 8 ) illustrate the difference. 
Taras Shevchenko National University of Kyiv

All the writing tasks were assessed by the teacher

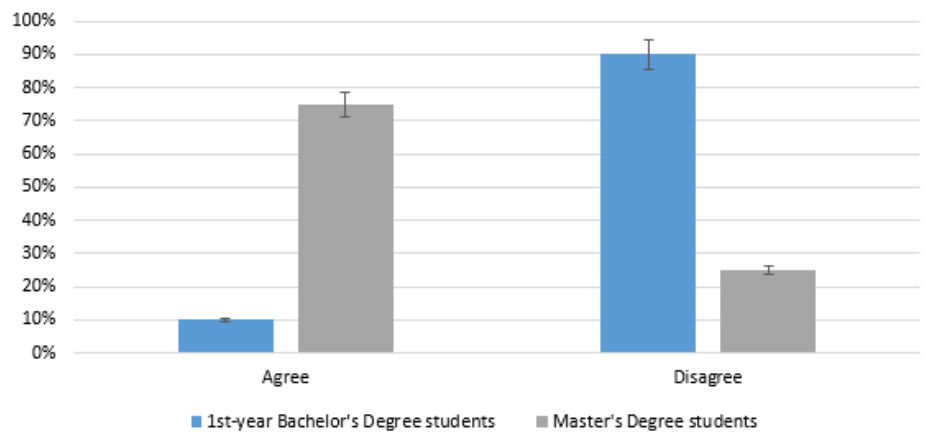

Fig. 7 The volume of the writing tasks assessed by the teacher at Taras Shevchenko National University of Kyiv in 2014 and 2020.

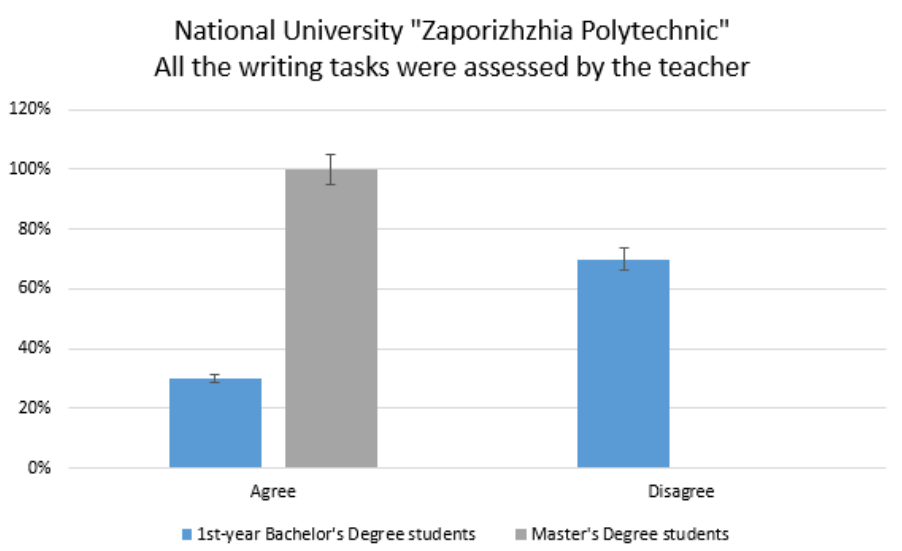

Fig. 8 The volume of the writing tasks assessed by the teacher at National University "Zaporizhzhia Polytechnic" in 2014 and 2020

Thus, the research has demonstrated that today in an ESP course not every single writing task is assessed by the teacher. Assessment is not used as a 'stick and carrot' approach any longer. Learning itself is more in focus, rather than grades.

\subsection{Error correction techniques and tools}

During the time span of 2014-2020, the approach to error correction has also changed. If before in most cases the teacher marked and corrected all the errors him/herself, now error correction has become more aimed at developing students' critical thinking through peer feedback and reflection skills. And the primary purpose of feedback is to stimulate learners to analyse their mistakes. The results of the survey can be seen in the following figures. 
Taras Shevchenko National University of Kyiv Methods of error correction

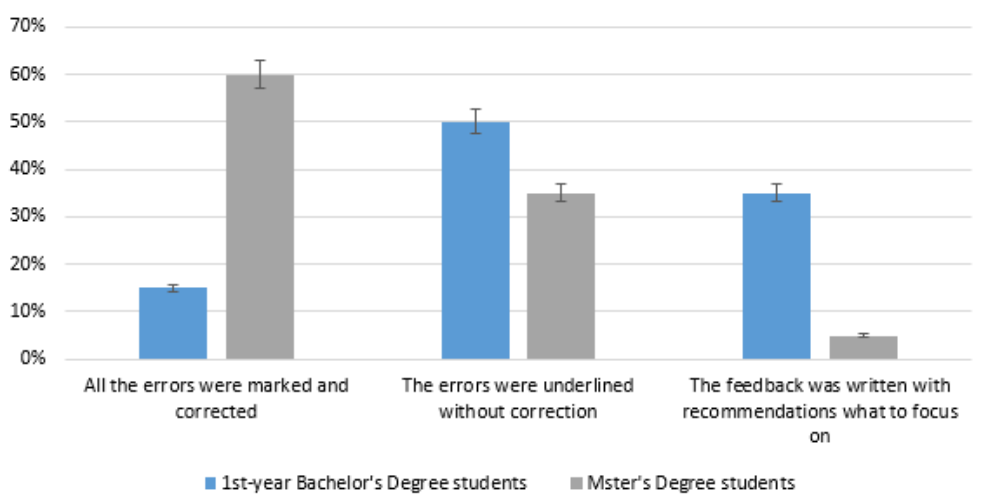

Fig. 9 Correlation of error correction methods for writing tasks at Taras Shevchenko National University of Kyiv in 2014 - 2020

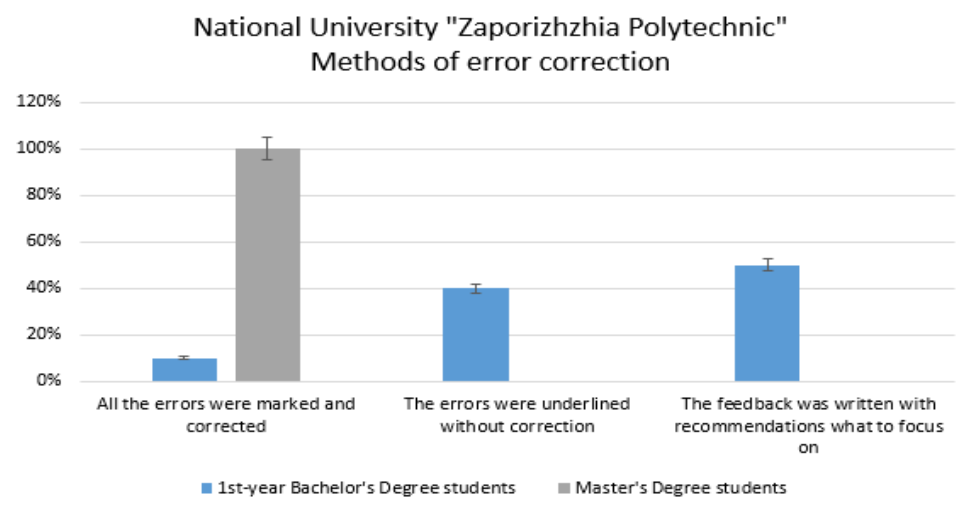

Fig. 10 Correlation of error correction methods for writing tasks at National University "Zaporizhzhia Polytechnic" in 2014 - 2020

As it is seen from the diagrams, in addition to conventional methods of error correction, when the teacher marks the mistakes and corrects them all, in both universities more advanced methods (coding and highlighting) were introduced. To facilitate students' analysis, coding techniques were introduced when the teacher underlines an error and codes it according to its type, where $G$ stands for a grammatical mistake, $S p$ for a spelling mistake, $W O$ for wrong word order, St for a stylistic mistake. Highlighting technique goes even further, when the teacher just underlines the error, and students themselves, using critical thinking, need to understand what is wrong there.

All of these instruments for error correction are accessible in digital form. A convenient platform for error correction is provided by Google documents where comments are left and addressed for further editing. With the growing involvement of $\mathrm{AI}$ and popularization of digital error correction tools, Grammarly and GradeProof applications are applied. In the comments to the survey, current Bachelor's degree students mentioned that they are aware of these tools and widely use them. 


\subsection{Approaches to teaching writing}

According to the results of the research, it appeared that in 2014 usually one of the approaches to teaching writing was used, but in 2020 the prevailing approach to teaching writing is a combination of the product, process and social-constructionist approaches (for the information on the approaches see Day et al. 2013, 14-19). The research findings can be found in the following figures:

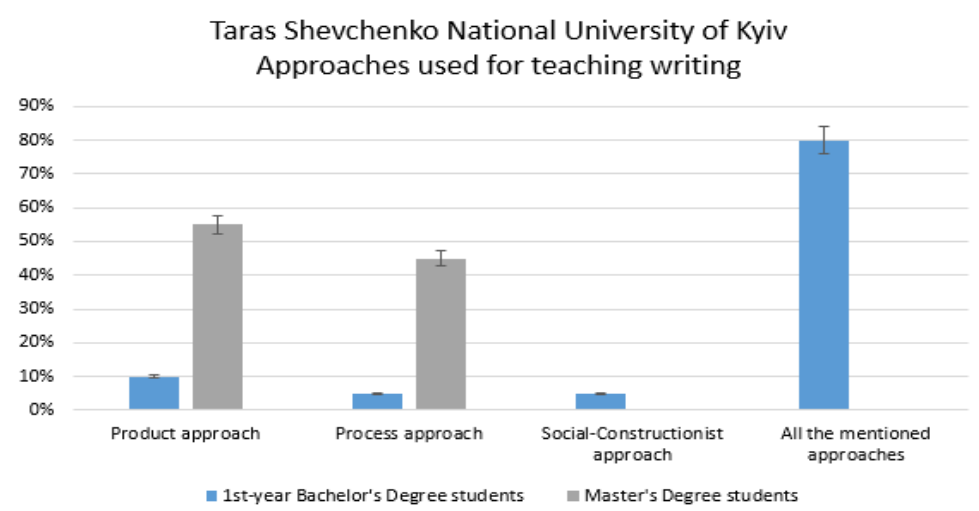

Fig. 11 Approaches to teaching writing skills used

at Taras Shevchenko National University of Kyiv in 2014 and 2020.

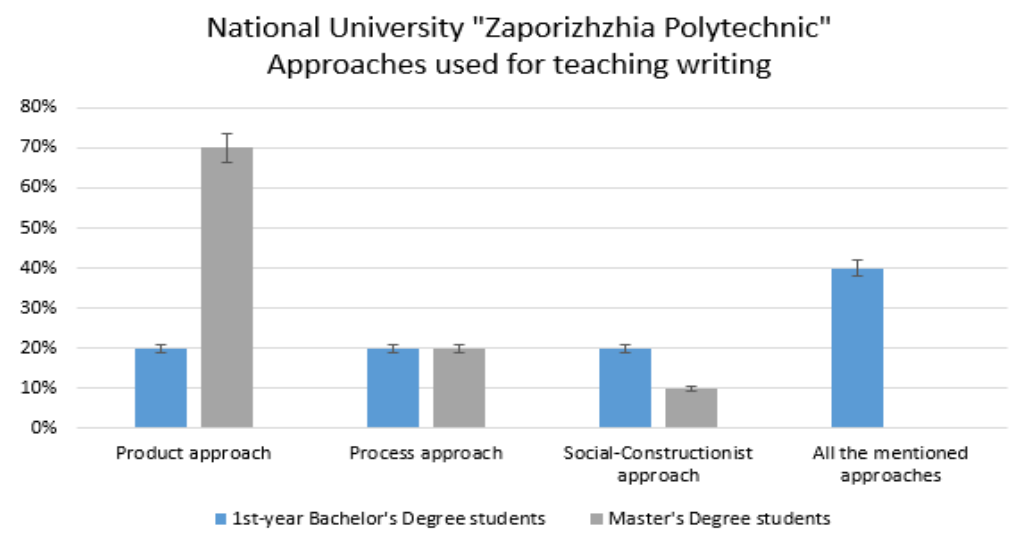

Fig. 12 Approaches to teaching writing skills used

at National University "Zaporizhzhia Polytechnic" in 2014 and 2020.

As it can be judged from the results of the survey, at both universities in 2014 the biggest focus was on either a Product approach or a Process approach, while a Social-Constructionist approach was almost ignored. The situation was changed after the "English for Universities" project: a combination of these three approaches is introduced in order to have students benefit from the advantages of each of the mentioned approaches. 


\section{LIMITATIONS OF THE RESEARCH}

The research findings were based on a small-scale study with a limited number of respondents. However, the general tendency was outlined and the scope of the investigation can be further expanded.

\section{CONCLUSION}

The main aim of this research was to study the context and content of teaching writing in two big universities of Ukraine, Taras Shevchenko National University of Kyiv and National University "Zaporizhzhia Polytechnic", before the British Council "English for Universities" project and after this project in order to evaluate its impact on teaching writing in the ESP course. The feedback gathered from the first-year Bachelor's degree students, who had this course in the 2019-2020 academic year and from the Master's degree students, who had this course in the 2014-2015 academic year enabled us to draw the following conclusions:

- increased relevance of today's writing text types, which now have become more job-related and better meet students' needs than before the project;

- now in an ESP course the advantages of in-class writing (drafting, proofreading, self-reflection and peer feedback) are widely used;

- after the project such tools as peer-feedback and self-reflection were introduced as the evaluation tools;

- formative assessment is more widely used for the learning purposes in teaching writing;

- error correction has become more aimed at developing students' critical thinking through peer feedback and reflection skills: coding and highlighting techniques are introduced for these purposes;

- a combination of three approaches (Product, Process and Social-Constructionist) is introduced now in order to let students benefit from the advantages of each of the mentioned approaches.

The research has demonstrated the great impact of the British Council "English for Universities" project on context and content of teaching Writing in an ESP course, that students now find this part of the course to be more relevant to their professional needs.

The prospects for further research lie in the domain of teaching writing online bearing in mind the 'new normal' (lockdown and distance learning), the benefits and limitations which this format has for an ESP course. For instance, the issues of transparency of assessment procedures and fostering students' academic integrity in general and under quarantine restrictions in particular. Even though few Bachelor's degree students produce research papers during their first year of study, they should realize the necessity of referencing and be made familiar with citation rules. This knowledge will also help them to design high-quality presentations or reports. 


\section{REFERENCES}

Balula, Ana, Vasconcelos, Sandra, Moreira, Antonio. "Developing academic skills in blended environments" The Journal of teaching English for Specific and academic purposes 7, no. 3 (2019): 303-309. Accessed May 20, 2020. http://espeap.junis.ni.ac.rs/index.php/espeap/ article/view/946

Bolitho, Rod, West, Richard. The Internationalisation of Ukrainian Universities: The English Language Dimension. Kyiv: Stal, 2017.

Borg, Simon. "The Impact of the English for Universities Project on ESP and EMI in Ukrainian Higher Education". British Council, 2019. Accessed July 10, 2020. https://www.britishcouncil.org.ua/sites/default/files/efu_impact_report_.pdf

Day, Jeremy, Frendo, Evan, Wright, Ros. Module 5 - Writing and written language. Trainer book. Certificate in Vocational English Teaching. British Council, 2013.

Dychka, Nataliia, Lazebna, Olena, Kotvytska Viktoriia. "Teaching students of Information Technology specialties English writing". Advanced Education 6 (2016): 11-15. Accessed May 31, 2020. http://ae.fl.kpi.ua/article/view/72947

"English for Universities". British Council. Accessed July 10, 2020. https://www.britishcouncil.org.ua/en/programmes/english/higher-education/englishfor-universities

Bakaieva, Halyna, Borysenko, Oksana, Ivanishcheva, Viktoriia, Khodtseva, Alla, Klymenko, Liudmyla, Kostrytska, Svitlana, Kozymirska, Tetiana, Skrypnyk, Tetiana, Todorova, Nataliia, Zuyenok, Iryna. English for Specific Purposes National Curriculum for Universities. Kyiv: Lenvit, 2005

Didenko, Iryna, Zhukova, Nataliia. "Overview of the writing subskills tested in the international ESP and EAP exams". 2020 https://docs.google.com/document/d/ 1vDq3FYv4xwTH5nDBltaTQj5dCWxAm69v4LSa_-GdfAw/edit?usp=sharing

Howard, Helen. "Looking to the future: Developing an academic skills strategy to ensure information literacy thrives in a changing higher education world". Journal of information literacy 6, no. 1, (2012): 72-81. Accessed May 21, 2020. http://dx.doi.org/10.11645/ 6.1.1677

Hyland, Ken. "ESP and Writing". In The Handbook of English for Specific Purposes, edited by Brian Paltridge, Sue Starfileld, 95-113. Wiley Blackwell, 2013.

Lubianova, Olesia. "Teaching technical writing as part of ESP" Advanced education 4 (2015): 36-39. Accessed May 21, 2020. http://ae.fl.kpi.ua/article/view/57043

Palka, Oleksandra. "Analysis of language needs for effective ESP syllabus design development" Państwo i Społeczeństwo 16, no. 2 (2016): 117-128. Accessed May 22, 2020. https://er.ucu.edu.ua/bitstream/handle/1/1012/Palka_Analyses\%20of\%20language. pdf? sequence $=6 \&$ isAllowed $=y$

Spratt, Mary, Pulverness, Alan, Williams, Melanie. The TKT Course: Modules 1, 2 and 3. Cambridge: Cambridge University Press, 2015

Tarnopolsky, Oleg. "Developing ESP students English speaking, reading, listening, and writing skills in Internet-assisted project work" The Journal of Teaching English for Specific and Academic Purposes 1, no. 1 (2013): 11-20. Accessed May 22, 2020. http://ir.duan.edu.ua/bitstream/123456789/1185/1/28-68-1-PB.pdf 